\title{
Prevalence of Toxoplasma gondii and Neospora caninum infections in households sheep "Elevage en case" in Dakar, Senegal
}

\author{
Laibané Dieudonné Dahourou ${ }^{1}$, Oubri Bassa Gbati ${ }^{2}$, Madi Savadogo ${ }^{3}$, Bernadette Yougbare ${ }^{4}$, Amadou Dicko ,
} Alima Hadjia Banyala Combari ${ }^{6}$ and Alain Richi Kamga-Waladjo ${ }^{3}$

1. Department of Animal Husbandry, Environmental Sciences and Rural Development Institute, University of Dedougou, P.O. Box 174, Dedougou, Burkina Faso; 2. Department of Public Health and Environment, Interstate school of Veterinary

Science and Medicine, P.O Box 5077, Dakar, Senegal; 3. Department of Biological Sciences and Animal Production,

Interstate School of Veterinary Sciences and Medicine, P.O Box 5077, Dakar, Senegal; 4. Department of Animal

Production, Environment and Agricultural Research Institute, P.O. Box 8645, Ouagadougou, Burkina Faso; 5. Centre Muraz, P.O Box 390, Bobo Dioulasso, Burkina Faso; 6. Department of Animal Production, Environment and Agricultural Research Institute, P.O Box 910, Bobo Dioulasso, Burkina Faso.

Corresponding author: Laibané Dieudonné Dahourou, e-mail: d_dahourou@yahoo.fr

Co-authors: OBG: oubribassa@yahoo.fr, MS: savadogo.madi@yahoo.fr, BY: yougbernadette@hotmail.fr, AD: dicko22@gmail.com, AHBC: alima.combari@gmail.com, ARK: akwar2003@yahoo.fr

Received: 05-01-2019, Accepted: 29-05-2019, Published online: 15-07-2019

doi: 10.14202/vetworld.2019.1028-1032 How to cite this article: Dahourou LD, Gbati OB, Savadogo M, Yougbare B, Dicko A, Combari AHB, Kamga-Waladjo AR (2019) Prevalence of Toxoplasma gondii and Neospora caninum infections in households sheep "Elevage en case" in Dakar, Senegal, Veterinary World, 12(7): 1028-1032.

\begin{abstract}
Aim: The study aimed to evaluate the occurrence of anti-Toxoplasma gondii and anti-Neospora caninum antibodies in sheep breeding in a particular husbandry system called "Elevage en case" in Dakar, Senegal.

Materials and Methods: Blood samples were collected from 278 sheep. Serum was harvested and used for analysis. For the detection of $T$. gondii antibodies, 278 sera were analyzed using the modified agglutination test, while the enzyme linkedimmunosorbent assay was used on 174 sheep sera to look for $N$. caninum antibodies.

Results: This study showed that $29.4 \pm 6.8 \%$ of sheep carried both $T$. gondii and $N$. caninum antibodies. The overall prevalence was $60.1 \pm 5.7 \%$ and $41.9 \pm 7.3 \%$ for toxoplasmosis and neosporosis, respectively. For toxoplasmosis, the prevalence was higher in Gueule Tapée (63.3\%) than in Medina (58.9\%), but the variation was not significant $(\mathrm{p}=0.45)$. Regarding the age of animals, the prevalence was significantly higher in animals over 2 years old compared to those under 2 years old $(\mathrm{p}=0.002)$. For neosporosis, the prevalence was significantly higher in Medina (48.67\%) than Gueule Tapée $(16.7 \%)(\mathrm{p}=0.001)$, but non-significant variation was noted according to animal age.
\end{abstract}

Conclusion: The study showed that sheep reared in households have carried antibodies of T. gondii and N. caninum. The prevalence was high and it means that consumption of meat from these animals is risky if the meat is eaten undercooked.

Keywords: Elevage en case, Neospora caninum, prevalence, Senegal, sheep, Toxoplasma gondii.

\section{Introduction}

Toxoplasma gondii and Neospora caninum are intracellular protozoa with worldwide distribution and high economic impact in husbandry system and public health importance [1]. They are responsible for zoonosis toxoplasmosis and neosporosis. Cats act as definitive host of $T$. gondii, and this parasite causes abortions, neonatal mortality or birth of stillborn in sheep [2]. It is a major cause of abortions and encephalitis in immunocompromised patients and can cause congenital defects in fetuses [3]. In pregnant women, ingestion of infected undercooked meat and contacts with oocysts spread by infected cats is recognized as important transmission risk factors

Copyright: Dahourou, et al. Open Access. This article is distributed under the terms of the Creative Commons Attribution 4.0 International License (http://creativecommons.org/licenses/ by/4.0/), which permits unrestricted use, distribution, and reproduction in any medium, provided you give appropriate credit to the original author(s) and the source, provide a link to the Creative Commons license, and indicate if changes were made. The Creative Commons Public Domain Dedication waiver (http:// creativecommons.org/publicdomain/zero/1.0/) applies to the data made available in this article, unless otherwise stated. of toxoplasmosis [4,5]. Dogs are definitive hosts of $N$. caninum which is an important cause of neonatal mortality and/or abortion in cattle and neuromuscular disorders in dogs, but there are no relevant reports of infection in human [1]. Transmission of $T$. gondii to sheep, as intermediate hosts, occurs when they ingest water or food contaminated by the parasite oocysts spread in the environment by cats [2]. A study carried out by Innes et al. [2] and Rodger et al. [6] have highlighted a possible vertical transmission of the parasite to sheep. Neosporosis is less frequent in sheep, and its role in sheep abortion is until now unclear, but Howe et al. [7] found an association between neosporosis and abortions in sheep in New Zealand. It is a cause of lambs mortality and congenital infections in naturally infected animals [8]. Sheep can be infected by ingesting oocysts spread by infected dogs, which indicate the possibility of horizontal infection [9].

In Senegal, sheep breeding plays an important social and economic role as it is a source of income for sheep owners and sheep are sacrificed during ceremonies such as Tabaski, baptisms, and weddings. In Dakar, sheep are kept in households in a particular husbandry 
system called "Elevage en case." In this system, people keep animals in enclosures located in apartments, at the top of buildings or backyard apartments, and the type of breeding is the most common in the town. In this breeding system, sheep are in regular contact with dogs and cats so that they could be exposed to toxoplasmosis and neosporosis. Indeed dogs and cats are identified to carry $N$. caninum and $T$. gondii, respectively, in Dakar [10,11]. In this context, meat from these sheep could be a source of parasites transmission through the consumption of meat. A study conducted by Kamga-Waladjo [10] revealed that these sheep are free of neosporosis, but their sampling size and sampling strategy were not appropriate to strongly inform on the infestation. Hence, additional studies are needed to assess the role of this animal in the epidemiology of toxoplasmosis and neosporosis in sheep.

Therefore, this study aimed to assess the prevalence and associated factors of toxoplasmosis and neosporosis in sheep from "Elevage en case" in Dakar.

\section{Materials and Methods}

\section{Ethical approval and informed consents}

Before each sampling, the aim of the study was explained to farmers. Farmers who accepted to participate in this study gave their oral consent before each animal sampling. Moreover, samples were collected by well-trained veterinarians with respect regarding animal welfare regulations.

\section{Study area}

This study was conducted in Medina and Gueule Tapée (Figure-1), two districts of Dakar (14 43'10"' $\mathrm{N}$ and $\left.17^{\circ} 28^{\prime} 21^{\prime \prime} \mathrm{W}\right)$, the capital city of Senegal. Médina is located at $14^{\circ} 40^{\prime} 51^{\prime \prime} \mathrm{N}$ and $17^{\circ} 26^{\prime} 58^{\prime \prime} \mathrm{W}$ while Gueule Tapée is at $14^{\circ} 41^{\prime} 19^{\prime \prime} \mathrm{N}$ and $17^{\circ} 27^{\prime} 31^{\prime \prime}$ W. These districts are one of the most inhabited and the oldest districts of Dakar. There is located in the south of Dakar. Most of the people who live in these districts keep sheep in their house. This sheep breeding is very developed with a predominant breeding

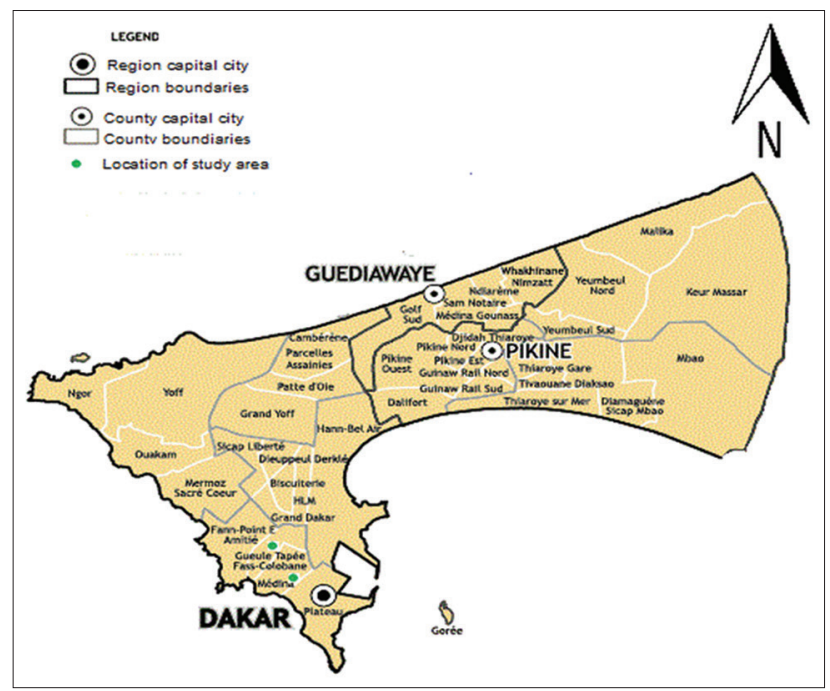

Figure-1: Study area map. (Source: Map was prepared by authors with the help of cartographer). system called "Elevage en case." Most of the sheep are sacrificed during religious and social celebrations.

The study was done from January to June 2014. Dakar is located in the subtropical area with Sahelian climate and the rainy season lasts from July to October. The lowest temperatures, between 15 and $18^{\circ} \mathrm{C}$ are noted from January to March while the highest temperatures, between 26 and $29^{\circ} \mathrm{C}$ run from June to September with an average of $24.3^{\circ} \mathrm{C}$. The amount of rainfall varies from year to year, with an average of $237 \mathrm{~mm}$. Wooded, shrubby, and herbaceous savannas are the main component of the vegetation. In Dakar, there is a high population of dogs and cats but most of these animals roam around the town.

\section{Sampling and data collection}

The sample size was estimated using the formula of Thrusfield [12] with an expected prevalence of $11.5 \%$ for toxoplasmosis [13] and $62 \%$ for neosporosis [10]. The confident level was $95 \%$ with a precision of $8 \%$. According to this approach, the minimal sample size was 141 animals, but we used 278 samples. In this study, 278 samples were used for anti-T. gondii antibodies detection and 174 samples for anti-N. caninum antibodies detection. Only animals kept in the breeding system "Elevage en case" were included in the sampling, and only females above 6 months were selected. The selected animals were fed with commercial feed and also peanut leaves. As there is a lot of wandering cats in these districts, these cats sometimes come into sheepfolds. As dogs are less abundant in the area, there is less contact between dogs and these sheep. For each selected animal, blood was collected, and a sampling form was filled, and it captured the following information: District, age, origin, and veterinary care of animals. The blood samples were taken to parasitology and mycology laboratory of the Ecole Inter-Etats des Sciences et Médecine Vétérinaires de Dakar where sera were extracted by centrifugation at $3000 \mathrm{rpm}$ for $15 \mathrm{~min}$, and stored in $-20^{\circ} \mathrm{C}$ until the time of the serological test.

\section{Serological analysis}

The modified agglutination test was used for the detection of anti- $T$. gondii antibodies with the commercial kit "Toxo-Screen DA" from Biomérieux, France (REF $75^{\circ} 481$ ). This test makes, in microplates, a direct agglutination of antigens of $T$. gondii with specific antibodies IgG of the parasites in animal sera. The dilution used was $1 / 40$. A positive reaction was the agglutination in the form of a veil lining about half of the bottom of the plate cup. For negative reaction, sedimentation of antigen as button or ring was observed. For the detection of anti-N. caninum antibodies, we used a competitive enzyme-linked immunosorbent assay (ELISA) test (VMRD Inc., Pullman, WA99163, and the USA) to detect in sera specific antibodies of this parasite.

For competitive ELISA, before serum samples analysis, ELISA reagents and plates were brought to 
room temperature. Then, 1X Antibody-Peroxidase Conjugate and 1X Wash Solution was prepared. Controls and serum samples were loaded in plates and plates were washed after $1 \mathrm{~h}$ of incubation. Then, we added in each plate the conjugate and we incubated plates for $20 \mathrm{~min}$. Plates were washed before adding substrate solution. After 20 min incubation, stop solution was added in each well of the plate before DO reading at $620 \mathrm{~nm}$. All incubations were made at room temperature, and all steps were run according to manufacturer instructions.

\section{Statistical analysis}

Statistical analysis was carried out using R software 2.13.0. Data on animal's age were coded by grouping it by age classes ( 6 months to 2 years; $2 \leq$ age $\leq 4$ years and $>4$ years). We used the Chi-square test and Fischer exact test, to test the differences of infestation between age classes, origin of animal, location, and veterinary care. For these tests, the statistical significance was set at 5\%.

\section{Results}

\section{Overall prevalence}

Antibodies against $T$. gondii were found in 167 sheep with an overall prevalence of $60.1 \%$ (Confidence Intervals [CI] 95\%: 55.1\%-66.5\%). For $N$. caninum, antibodies were detected in 73 sheep with an overall prevalence of $41.9 \%$ (CI 95\%: 34.6\%$49.2 \%$ ). The overall prevalence of coinfections was 29.4\% (CI 95\%:22.6\%-36.2\%).

\section{Associated factors regarding $T$. gondii}

The prevalence of $T$. gondii varied between location, age, origin of sheep, and existence of veterinary care (Table-1). The prevalence of $T$. gondii antibodies was $58.9 \%$ and $63.3 \%$, respectively, in Médina and Gueule Tapée, but the variation was not significant $(p=0.449)$. The prevalence was higher in animals over 2 years old compared to animal under 2 years old $(p=0.02)$. Animals from farms visited by a veterinarian were less infected than farms without any veterinary care $(\mathrm{p}=0.09)$.

\section{Associated factors regarding $\mathbf{N}$. caninum}

Data on factors associated with the risk of $N$. caninum are detailed in Table- 2 . The prevalence was significantly higher in Médina (48.6\%) than Gueule Tapée $(16.7 \%) \quad(\mathrm{p}=0.001)$. Animals over 2 years old were most infected, but the variation was not significant $(\mathrm{p}=0.728)$.

\section{Discussion}

In this study, only females were selected. This study was made to collect data for future analysis of abortion causes in sheep, and parasites diseases were one of the targeted causes.

In Senegal, mutton from sheep is a relevant source of proteins for many people. However, these animals play a key role in the epidemiology of more meat-borne diseases. In toxoplasmosis, ingestion of undercooked infected meat can cause infection in human [5].

In this study, the prevalence of coinfections was $29.4 \pm 6.8 \%$. The presence of antibodies against these two parasites is a major public health issue even if the zoonotic potential of $N$. caninum was not demonstrated. Antibodies of this parasite were found in human [14].

Regarding T. gondii, the prevalence found could be associated with the high population of stray cats that could come close to farms and contaminate animals living environment with the oocysts. The link between presence and number of stray cats and the high prevalence of toxoplasmosis in intermediate hosts was demonstrated by Fajardo et al. [15]. Moreover, animals in theses farms lived so close to each other, and this situation could be an occasion for each animal to be infected by ingesting food or water contaminated by oocysts shed by cats. The prevalence found in this study was higher than found in West African countries [16-18]. This difference with studies in Senegal and Cote d'Ivoire could be due to the fact that animals were reared in extensive systems living in very large areas with low contact with cats. In Togo, the study was done in dry season, which is not favorable for the

Table-1: Factors associated with the infection with Toxoplasma gondii in sheep, Dakar, Senegal, 2014.

\begin{tabular}{|c|c|c|c|c|}
\hline Variables & No. tested & No. positives & Prevalence (\%) and $\mathrm{CI}$ at $95 \%$ & p-value \\
\hline \multicolumn{5}{|l|}{ Districts } \\
\hline Médina & 158 & 93 & $58.9 \pm 7.6^{a}$ & 0.449 \\
\hline Gueule Tapée & 120 & 76 & $63.3 \pm 8.6^{a}$ & \\
\hline \multicolumn{5}{|l|}{ Age classes } \\
\hline $0.5-2$ years & 109 & 53 & $48.6 \pm 9.3^{a}$ & 0.002 \\
\hline $2-4$ years & 115 & 76 & $66.1 \pm 8.6^{b}$ & \\
\hline$>4$ years & 54 & 40 & $74.1 \pm 11.7^{b}$ & \\
\hline \multicolumn{5}{|l|}{ Sheep origin } \\
\hline Born in the farm & 242 & 144 & $59.5 \pm 6.1^{\mathrm{a}}$ & 0.254 \\
\hline Buy & 36 & 25 & $69.4 \pm 15^{a}$ & \\
\hline \multicolumn{5}{|l|}{ Veterinary care } \\
\hline Yes & 109 & 73 & $67 \pm 8.8^{a}$ & 0.09 \\
\hline No & 169 & 96 & $56.8 \pm 7.4^{a}$ & \\
\hline Total & 278 & 167 & $60.1 \pm 5.7$ & \\
\hline
\end{tabular}

*Within each variable, prevalence rates with different superscripts are statistically different $(p<0.05) . C I=C o n f i d e n c e$ intervals 
Table-2: Factors associated with the infection to Neospora caninum in sheep, Dakar, Senegal, 2014.

\begin{tabular}{|c|c|c|c|c|}
\hline Variables & No. tested & No. positives & Prevalence $(\%)$ and $\mathrm{CI}$ at $95 \%$ & p-value \\
\hline \multicolumn{5}{|l|}{ Districts } \\
\hline Médina & 138 & 67 & $48.6 \pm 8.3^{\mathrm{a}}$ & 0.001 \\
\hline Gueule Tapée & 36 & 6 & $16.7 \pm 12.2^{\mathrm{b}}$ & \\
\hline \multicolumn{5}{|l|}{ Age classes } \\
\hline $0.5-2$ years & 68 & 26 & $38.2 \pm 11.5^{\mathrm{a}}$ & 0.728 \\
\hline $2-4$ years & 70 & 31 & $44.3 \pm 11.6$ a & \\
\hline$>4$ years & 36 & 16 & $44.4 \pm 16.2^{\mathrm{a}}$ & \\
\hline \multicolumn{5}{|l|}{ Sheep origin } \\
\hline Born in the farm & 147 & 58 & $39.5 \pm 8^{\mathrm{a}}$ & 0.119 \\
\hline Buy & 27 & 15 & $55.6 \pm 18.7^{a}$ & \\
\hline \multicolumn{5}{|l|}{ Veterinary care } \\
\hline Yes & 68 & 23 & $33.8 \pm 11.2^{a}$ & 0.082 \\
\hline No & 106 & 50 & $47.2 \pm 9.5^{\mathrm{a}}$ & \\
\hline Total & 174 & 73 & $41.9 \pm 7.3$ & \\
\hline
\end{tabular}

*Within each variable, prevalence rates with different superscripts are statistically different $(p<0.05)$. CI=Confidence intervals

survival of oocysts in the environment. The prevalence was similar to 58.8\% in Burkina Faso [19] and 58.7\% in Ethiopia [20]. Using ELISA test, $16 \%$ in Senegal [10], 30.5\% in Ghana [22], 31.8\% in Ethiopia [23], $8 \%$ in South Africa [24], and $6.7 \%$ in Nigeria [25], prevalence's were observed. Through an indirect immunofluorescence test, a prevalence of $38 \%$ was found in Egypt [26]. The prevalence has increased according to the age of animals because older animals have been more exposed to parasite oocysts compared to younger animals.

For neosporosis, the overall prevalence was 41.9\%. However, in Africa, fewer studies have been conducted on sheep neosporosis even if molecular data have confirmed the infection in sheep in North Africa [27]. Kamga-Waladjo [10] found a prevalence of $0 \%$ and $62 \%$, respectively, in sheep of the same production system and sheep from the extensive production system in Senegal. In the study of Kamga, sheep herds with low density were used and the study was made in few farms followed along a year. With the same test, a prevalence of $27.7 \%$ was found in Pakistan [28] and 7.3\% in China [29]. This prevalence was $59.23 \%$ in Brazil [30]. In our study, the prevalence was significantly higher in Médina than Gueule Tapée $(\mathrm{p}<0.05)$. This difference could be associated with sampling strategy as more animals were selected in Medina.

\section{Conclusion}

This study showed that most of the sheep kept in the system "Elevage en case" in Dakar had antibodies against $T$. gondii and $N$. caninum. The meat of sheep could also be associated with the transmission of these diseases mainly toxoplasmosis to human. Sensitization actions should be implemented to inform people about the risk factors and prevention ways, mostly the good cooking of sheep meat.

\section{Authors' Contributions}

ARK and LDD designed, followed up the study and analyzed the data. LDD, MS, BY, AD, and AHBC have collected data from the field and made laboratory analysis. LDD proposed a draft of the manuscript. MS, BY, AHBC, AD, ARK, and OBG reviewed and corrected the manuscript as per reviewer comments. All authors read and approved the final manuscript.

\section{Acknowledgments}

The authors are grateful to sheep owners who accepted to participate in this study. We would also like to thank the laboratory technicians, mainly Mr. Cheikhouna Diatta for his assistance during laboratory analysis. We would also like to thank Wilson Kaumbata from Malawi for proofreading the manuscript. The authors did not receive any fund for this study.

\section{Competing Interests}

The authors declare that they have no competing interests.

\section{Publisher's Note}

Veterinary World remains neutral with regard to jurisdictional claims in published map and institutional affiliation.

\section{References}

1. Dubey, J.P., Schares, G. and Ortega-Mora, L.M. (2007) Epidemiology and control of neosporosis and Neospora caninum. Clin. Microbiol. Rev., 20(2): 323-367.

2. Innes, E.A., Bartley, P.M., Buxton, D. and Katzer, F. (2009) Ovine toxoplasmosis. Parasitology, 136(14): 1887-1894.

3. Montoya, J.G. and Liesenfeld, O. (2004) Toxoplasmosis. The Lancet, 363(9425): 1965-1976.

4. Agmas, B., Tesfaye, R. and Koye, D.N. (2015) Seroprevalence of Toxoplasma gondii infection and associated risk factors among pregnant women in Debre Tabor, Northwest Ethiopia. BMC Res. Notes, 8(1): 107.

5. Hill, D.E. and Dubey, J.P. (2018) Toxoplasma gondii. In: Ortega, Y. and Sterling, C., editors. Foodborne Parasites. Food Microbiology and Food Safety. Springer, New York. p119-138.

6. Rodger, S.M., Maley, S.W., Wright, S.E., Mackellar, A., Wesley, F., Sales, J. and Buxton, D. (2006) Role of endogenous transplacental transmission in toxoplasmosis in sheep. Vet. Rec., 159(23): 768-772.

7. Howe, L., West, D.M., Collett, M.G., Tattersfield, G., 
Pattison, R.S., Pomroy, W.E., Kenyon, P.R., Morris, S.T. and Williamson, N.B. (2008) The role of Neospora caninum in three cases of unexplained ewe abortions in the southern North Island of New Zealand. Small Rumin. Res., 75(2): 115-122.

8. Helmick, B., Otter, A., McGarry, J. and Buxton, D. (2002) Serological investigation of aborted sheep and pigs for infection by Neospora caninum. Res. Vet. Sci., 73(2): 187-189.

9. O'Handley, R., Liddell, S., Parker, C., Jenkins, M.C. and Dubey, J.P. (2002) Experimental infection of sheep with Neospora caninum oocysts. J. Parasitol., 88(6): 1120-1123.

10. Kamga-Waladjo (2009) Incidence de la prevalence sérologique de Neospora caninum sur la reproduction des animaux d'élevage au Sénégal. Université Polytechnique de Bobo Dioulasso, Bobo Dioulasso (Burkina Faso).

11. Ndour, A.P.N. (2012) Analysis of T. gondii transmission risk to woman in Dakar region (Senegal). Ecole Inter-Etats des Sciences et Médecine Vétérinaires de Dakar, Dakar (Sénégal). This document was originally published in French.

12. Thrusfield, M. (2007) Veterinary Epidemiology. $3^{\text {rd }}$ ed. Wiley-Blackwell, Hoboken, New Jersey, États-Unis. p624.

13. Deconinck, P., Pangui, L.J., Akakpo, J., Garrouste, A., Ouattara, L., Roger, F., Robert, T. and Dorchies, P. (1996) Seroepidemiology of toxoplasmosis in sheep and goat from Africa. Rev. Méd. Vét., 147(5): 377-378. This article was originally published in French.

14. Lobato, J., Silva, D.A.O., Mineo, T.W.P., Amaral, J.D.H., Segundo, G.R.S., Costa-Cruz, J.M., Ferreira, M.S., Borges, A.S. and Mineo, J.R. (2006) Detection of immunoglobulin $\mathrm{G}$ antibodies to Neospora caninum in humans: High seropositivity rates in patients who are infected by human immunodeficiency virus or have neurological disorders. Clin. Vaccine Immunol., 13(1): 84-89.

15. Fajardo, H.V., D'ávila, S., Bastos, R.R., Cyrino, C.D., De Lima Detoni, M., Garcia, J.L., Das Neves, L.B., Nicolau, J.L. and Amendoeira, M.R.R. (2013) Seroprevalence and risk factors of toxoplasmosis in cattle from extensive and semi-intensive rearing systems at Zona da Mata, Minas Gerais state, Southern Brazil. Parasit. Vectors, 6(1): 191.

16. Koné, P., Kamga-Waladjo, A.R., Daya, Y.C.A. and Ouattara, M. (2008) Retrospective study of ovine toxoplasmosis on Djallonké sheep in Côte d'Ivoire. Rev. Afr. Santé Prod. Anim., 6(2): 123-125. This article was originally published in French.

17. Bastiaensen, P., Dorny, P., Batawui, K., Boukaya, A., Napala, A. and Hendrickx, G. (2003) Small ruminant parasitism in the suburban area of Sokode, Togo. I. sheep. Rev. Elev. Méd. Vét. Pays Trop., 56(1-2): 43. This article was originally published in French.

18. Davoust, B., Mediannikov, O., Roqueplo, C., Perret, C., Demoncheaux, J.P., Sambou, M., Guillot, J. and Blaga, R. (2015) Serological survey of animal toxoplasmosis in Senegal Bull. Soc. Pathol. Exot., 108(1): 73-77. This article was originally published in French.

19. Bamba, S., Faye, B., Tarnagda, Z., Boly, N., Guiguemdé, T. and Villena, I. (2012) Seroprevalence of toxoplasmosis in sheep in Bobo-Dioulasso, Burkina Faso. Rev. Elev. Méd. Vét. Pays Trop., 65(3-4): 63-66. This article was originally published in French.

20. Tegegne, D., Kelifa, A., Abdurahaman, M. and Yohannes, M. (2016) Seroepidemiology and associated risk factors of Toxoplasma gondii in sheep and goats in Southwestern Ethiopia. BMC Vet. Res., 12(1): 280.

21. Sawadogo, P., Hafid, J., Bellete, B., Sung, R.T.M., Chakdi, M., Flori, P., Raberin, H., Hamouni, I.B., Chait, A. and Dalal, A. (2005) Seroprevalence of T. gondii in sheep from Marrakech, Morocco. Vet. Parasitol., 130(1): 89-92.

22. Van der Puije, W.N.A., Bosompem, K.M., Canacoo, E.A., Wastling, J.M. and Akanmori, B.D. (2000) The prevalence of anti-Toxoplasma gondii antibodies in Ghanaian sheep and goats. Acta Trop., 76(1): 21-26.

23. Gebremedhin, E.Z., Agonafir, A., Tessema, T.S., Tilahun, G., Medhin, G., Vitale, M. and Di Marco, V. (2013) Some risk factors for reproductive failures and contribution of Toxoplasma gondii infection in sheep and goats of central Ethiopia: A cross-sectional study. Res. Vet. Sci., 95(3): 894-900.

24. Hammond-Aryee, K., Helden, V.S.L. and Helden, V.D.P. (2015) The prevalence of antibodies to Toxoplasma gondii in sheep in the Western Cape, South Africa. Onderstepoort J. Vet. Res., 82(1): 1-5.

25. Kamani, J., Mani, A.U. and Egwu, G.O. (2010) Seroprevalence of Toxoplasma gondii infection in domestic sheep and goats in Borno state, Nigeria. Trop. Anim. Health Prod., 42(4): 793-797.

26. Al-Kappany, Y.M., Abbas, I.E., Devleesschauwer, B., Dorny, P., Jennes, M. and Cox, E. (2018) Seroprevalence of anti-Toxoplasma gondii antibodies in Egyptian sheep and goats. BMC Vet. Res., 14(1): 120.

27. Amdouni, Y., Rjeibi, M.R., Awadi, S., Rekik, M. and Gharbi, M. (2018) First detection and molecular identification of Neospora caninum from naturally infected cattle and sheep in North Africa. Transbound. Emerg. Dis., 65(4): 976-982.

28. Nasir, A., Ashraf, M., Khan, M.S., Javeed, A., Yaqub, T., Avais, M. and Reichel, M.P. (2012) Prevalence of Neospora caninum antibodies in sheep and goats in Pakistan. $J$. Parasitol., 98(1): 213-215.

29. Wang, S., Li, L., Lu, Y., Zhang, H., Xie, Q. and Zhang, Z. (2018) Seroprevalence and risk factors of Neospora caninum infection among domestic sheep in Henan province, central China. Parasite, 25(1): 15.

30. Paiz, L.M., da Silva, R.C., Menozzi, B.D. and Langoni, H. (2015) Antibodies to Neospora caninum in sheep from slaughterhouses in the state of São Paulo, Brazil. Rev. Bras. Parasitol. Vet., 24(1): 95-100. 